\title{
Performance of Tension Lap-Splice in Lightweight Concrete
}

\author{
Wael Ibrahim, Rana Ahmed
}

\begin{abstract}
The use of Light-Weight Concrete (LWC) in modern construction has resulted in efficient designs and considerable cost savings by reducing structural own weight and supporting footings sections. The purpose of this paper is to investigate the Lap-Splice behavior between LWC and steel reinforcement (RFT). The tested specimens were divided into four groups to study the effect of main variables: steel reinforcement bar size, internal confinement (stirrups), splice length and concrete cover thickness. Four-point bending tests were carried out on test specimens to evaluate the performance of lap splices under pure bending. Bond behavior and failure modes were noted to be similar in the normal concrete and in the LWC. In tested beams, it was observed that the bar size has a significant influence on the mean bond stress in the splice. Improving radial tensile strength by using increasing stirrups number improves the bond behavior. The splice length up to 35 times bar diameter decreased the moment capacity of beam. The splice length of 55 times bar diameter results in the same capacity of the beam without any splice.
\end{abstract}

Keywords: LWC, RC Beams, Splice length, Bond Behavior.

\section{INTRODUCTION}

In the last ten years, the interest in lightweight concrete "LWC" grows rapidly and now it is widely used in building construction. Due to the advantage of its low density, this results in a significant benefit in terms of load bearing elements of smaller cross section [1], [2], [3]. Adequate bond between lightweight concrete and reinforcing bars in a splice is an essential requirement in the design of reinforced concrete structure. Many researches were reported on bond strength between concrete and deformed bars for both normal strength and high strength concrete [4], [5], [6]. Experimental tests were done and analytical equations were proposed by some researchers. But more knowledge on the mechanical interaction "bond" between reinforcing bars and lightweight concrete is need [7], [8]. However, it is well known that there are only few experimental investigations about the performance of tension lap-splice in LWC [9], [10]. Twelve full-scale beam specimens $(2000 \times 300 \times 200 \mathrm{~mm})$ were tested in positive bending. The specimens of lap-splice series were tested with lap-spliced bars centred on the mid span in a

Revised Manuscript Received on February 05, 2020.

* Correspondence Author

Wael Ibrahim*, Civil Department, Faculty of Engineering at Mataria, Helwan University, Cairo, Egypt. Email: wael.ibrahim@rwth-aachen.de

Rana Ahmed, Civil Department, Faculty of Engineering at Mataria, Helwan University, Cairo, Egypt.. Email: Ranahmed@hotmail.com

(C) The Authors. Published by Blue Eyes Intelligence Engineering and Sciences Publication (BEIESP). This is an open access article under the CC BY-NC-ND license (http://creativecommons.org/licenses/by-nc-nd/4.0/) region of constant positive bending. The main variables were, steel reinforcement bar size, internal confinement (stirrups), lap splice length and concrete cover. Thus, the lap splice is considered the most economic and the easiest way for splicing the reinforcing steel bars. Therefore, a research program has been started aiming on a better experimentally supported database for generating performance of tension lap-splice in LWC for future codes.

\section{EXPERIMENTAL PROGRAM}

\section{A. Experimental program matrix}

The experimental program matrix consists of 12 reinforced concrete beams as show in Table I. The reinforced concrete beams are divided into four groups, a control group without Lap-Splice and three groups with Lap-Splice. The beam study having a total length $(\mathrm{L}=2000 \mathrm{~mm}$ ), overall depth ( $\mathrm{h}=$ $300 \mathrm{~mm}$ ) and width (b=200 mm). The RC beams are reinforced with $2 \varnothing 10$ as top reinforcement and $2 \varnothing 10$ as bottom reinforcement as show in figure (1).

Table- I: Experimental program matrix

\begin{tabular}{|c|c|c|c|c|c|}
\hline Group & Beam & $\begin{array}{c}\text { Concrete } \\
\text { Type }\end{array}$ & $\begin{array}{c}\text { Spliced } \\
\text { Length } \\
\text { mm }\end{array}$ & $\begin{array}{c}\text { Stirrups } \\
\mathbf{n} / \mathbf{m}^{\prime}\end{array}$ & $\begin{array}{c}\text { Cover } \\
\text { mm }\end{array}$ \\
\hline \multirow{4}{*}{ G1 } & B1 & NWC & 550 & $7 \varnothing 8$ & 20 \\
\hline & B2 & LWC & 550 & $7 \varnothing 8$ & 20 \\
\hline & B3 & NWC & 550 & $7 \varnothing 8$ & 20 \\
\hline & B4 & LWC & 550 & $7 \varnothing 8$ & 20 \\
\hline \multirow{3}{*}{ G2 } & B5 & \multirow{8}{*}{ LWC } & 880 & $7 \varnothing 8$ & 20 \\
\hline & B6 & & 1210 & $7 \varnothing 8$ & 20 \\
\hline & B7 & & 550 & $7 \varnothing 8$ & 20 \\
\hline \multirow{3}{*}{ G3 } & B8 & & 550 & $7 \varnothing 8$ & 20 \\
\hline & B9 & & 350 & $10 \varnothing 8$ & 20 \\
\hline & $\mathrm{B} 10$ & & 450 & $7 \varnothing 8$ & 20 \\
\hline \multirow{2}{*}{ G4 } & B11 & & 550 & $7 \varnothing 8$ & 10 \\
\hline & B12 & & 550 & $7 \varnothing 8$ & 40 \\
\hline
\end{tabular}

\begin{tabular}{|c|c|c|c|c|c|}
\hline Group & Beam & $\begin{array}{c}\text { Concrete } \\
\text { Type }\end{array}$ & Top RFT & $\begin{array}{c}\text { Bottom } \\
\text { RFT }\end{array}$ & $\begin{array}{c}\text { Spliced } \\
\text { Length } \\
\text { mm }\end{array}$ \\
\hline \multirow{4}{*}{$\begin{array}{c}\text { G1 } \\
\text { Control }\end{array}$} & B1 & NWC & \multirow{16}{*}{$\stackrel{\circ}{\stackrel{Q}{Q}}$} & $2 \varnothing 10$ & non \\
\hline & B2 & LWC & & $2 \varnothing 10$ & non \\
\hline & B3 & NWC & & $2 \varnothing 10$ & 550 \\
\hline & B4 & LWC & & $2 \varnothing 10$ & 550 \\
\hline G2 & B4 & \multirow{12}{*}{ LWC } & & $2 \varnothing 10$ & 550 \\
\hline Lap & B5 & & & $2 \varnothing 10$ & 450 \\
\hline Splice & B6 & & & $2 \varnothing 10$ & 350 \\
\hline \multirow{3}{*}{$\begin{array}{c}\text { G3 } \\
\text { Bar size }\end{array}$} & B4 & & & $2 \varnothing 10$ & 550 \\
\hline & B7 & & & $2 \varnothing 16$ & 880 \\
\hline & B8 & & & $2 \varnothing 22$ & 1210 \\
\hline \multirow{3}{*}{$\begin{array}{c}\text { G4 } \\
\text { Stirrups } \\
\text { Spacing }\end{array}$} & B4 & & & $2 \varnothing 10$ & 550 \\
\hline & B9 & & & $2 \varnothing 10$ & 550 \\
\hline & B10 & & & $2 \varnothing 10$ & 550 \\
\hline \multirow{3}{*}{$\begin{array}{c}\text { G5 } \\
\text { Concrete } \\
\text { Cover }\end{array}$} & B4 & & & $2 \varnothing 10$ & 550 \\
\hline & B11 & & & 2010 & 550 \\
\hline & B12 & & & & 550 \\
\hline
\end{tabular}




\section{Performance of Tension Lap-Splice in Lightweight Concrete}

\section{B. Material Properties}

The average compressive strength of the concrete based on ACI - 318 [1] is $25 \mathrm{MPa}$ and the average tensile strength is $2.50 \mathrm{MPa}$. The average yield strength of steel reinforcement is $400 \mathrm{MPa}$ with a modulus of elasticity of $200 \mathrm{GPa}$ (DIN 50145) [4] and the ultimate strength is $600 \mathrm{MPa}$.
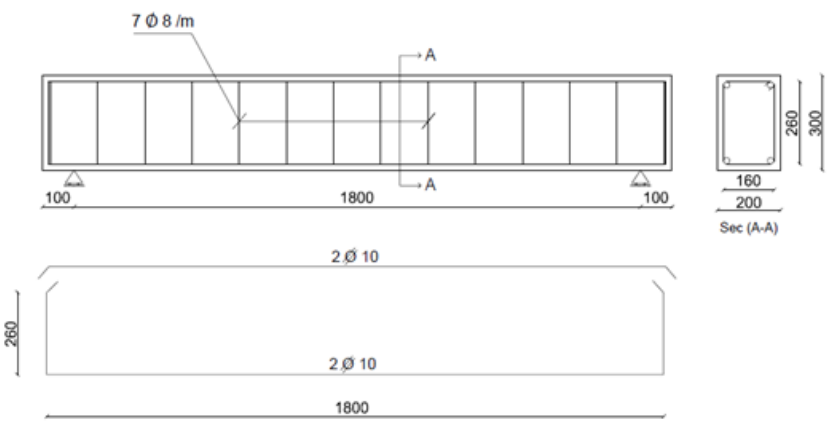

Fig. 1. Specimen dimensions and reinforcement details.

\section{Test Set-up}

The beams were tested at their age of 28 days. One day before testing, two sides of each beam were painted to facilitate the tracing of cracks and its propagation during loading. At the day of testing, the beams were mounted and adjusted, one by one, in the testing frame in which the beams were tested using four point bending configuration to develop a constant moment region along the middle third of the span at which the spliced length of the bars locates. In order to ease the construction of the beams; their length had been kept constant as $2000 \mathrm{~mm}$ which led to use the same test setup for all the beams as shown in figure (2).The test setup allowed a constant moment region of $600 \mathrm{~mm}$ along the middle third where the splice length is located and two shear spans at the terminal thirds $600 \mathrm{~mm}$ each. The beams were supported at $100 \mathrm{~mm}$ apart from the both ends using two metal beams restrained to a horizontal flat surface of the testing frame.

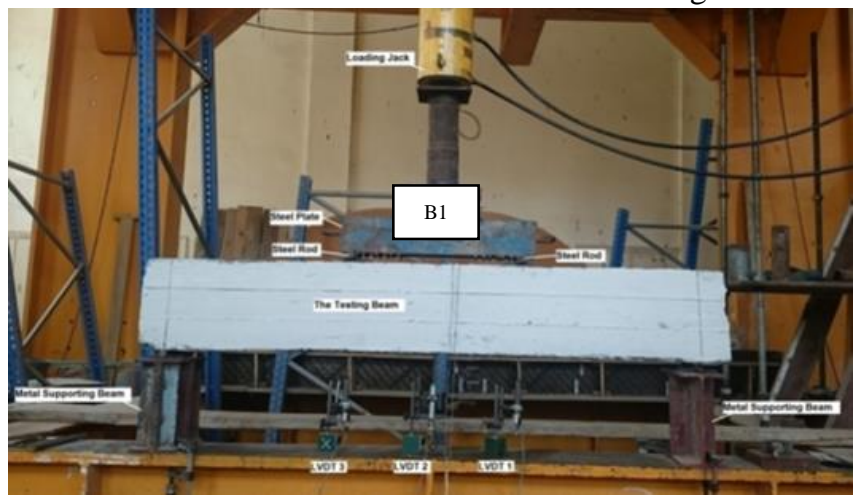

Fig. 2.Test Set-up.

\section{Instrumentation}

In order to record the beams vertical deflection, three vertical LVDT gages of $0.001 \mathrm{~mm}$ accuracy were used under beams at the mid span as well as the two thirds of the span between the two supports as shown in figure (3). The LVDTs were connected to the data acquisition system. The mid-span tensile steel strain (S1) was measured by one electrical strain gauge of 20-mm length and 120-Ohm resistance.
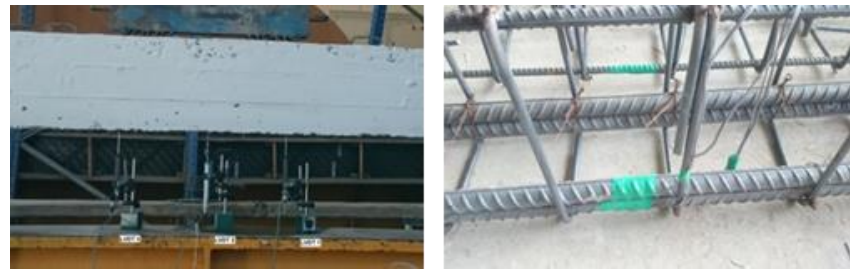

Fig. 3.LVDT and Strain gauges positions.

\section{TEST RESULTS AND DISCUSSION}

This experimental program is conducted in order to study the behaviour of reinforced polystyrene lightweight concrete beams (LWC) with overlapped splices in the region of max positive tension and comparing them with similar normal weight concrete beams (NWC). The program included the testing of ten LWC beams and two NWC beams as a reference. Failure mode, load deflection and failure loads of the tested specimens are obtained from the experimental study and presented comparatively. The study focused on the influence of 5 parameters on the lapped splices within LWC beams. Those studied parameters can be summarized as follows:

1. The type of concrete, by comparing the behaviour of splices in LWC beams with those in NWC beams having the same value of compressive strength of $25 \mathrm{MPa}$.

2. The size of the spliced reinforcement bars, by comparing spliced bars with three different sizes of $\{10 \mathrm{~mm}, 16 \mathrm{~mm}$ and $22 \mathrm{~mm}$.

3. The spacing between stirrups, by comparing three uniform stirrups spacing $\{100 \mathrm{~mm}, 150 \mathrm{~mm}$ and $200 \mathrm{~mm}$.

4. The spliced length, by comparing three splicing lengths $\{35 \varnothing, 45 \varnothing$ and $55 \varnothing\}$.

5. The bottom concrete cover depth, by comparing three concrete cover depths $\{10 \mathrm{~mm}, 20 \mathrm{~mm}$ and $40 \mathrm{~mm}\}$.

The test results were presented in Table II and will be described in the following.

Table- II: Experimental results

\begin{tabular}{|c|c|c|c|c|c|}
\hline Beam & $\begin{array}{c}\text { L splice } \\
(\mathrm{mm})\end{array}$ & $\begin{array}{l}P_{\text {crack }} \\
(k N)\end{array}$ & $\begin{array}{c}P_{\text {Ultimate }} \\
(k N)\end{array}$ & $\begin{array}{l}\text { Failure } \\
\text { Mode }\end{array}$ & $\begin{array}{c}f_{b} \text { Avg. } \\
\{\mathrm{ACl}\} \\
(\mathrm{MPa})\end{array}$ \\
\hline B1 & - & 42 & 95 & \multirow{4}{*}{$\begin{array}{c}\text { Flexur } \\
\text { al } \\
\text { Mode }\end{array}$} & - \\
\hline B2 & - & 46 & 94 & & - \\
\hline B3 & \multirow{2}{*}{550} & 47 & 94 & & 1.34 \\
\hline B4 & & 52 & 93 & & 1.41 \\
\hline B5 & 880 & 74 & 173 & \multirow{2}{*}{$\begin{array}{l}\text { Shear } \\
\text { Mode }\end{array}$} & 1.30 \\
\hline B6 & 1210 & 129 & 242 & & 1.18 \\
\hline B7 & 550 & 53 & 96 & $\begin{array}{c}\text { Flexur } \\
\text { al }\end{array}$ & 1.57 \\
\hline
\end{tabular}




\begin{tabular}{|c|c|c|c|c|c|}
\hline B8 & & 51.4 & 92 & Mode & 1.12 \\
\hline B9 & 350 & 50 & 82 & & 1.99 \\
\cline { 1 - 1 } B10 & 450 & 50 & 91 & & 1.57 \\
\cline { 1 - 1 } B11 & \multirow{2}{*}{550} & 47 & 92 & & 1.26 \\
\cline { 1 - 1 } B12 & & 55 & 91 & & 1.48 \\
\hline
\end{tabular}

\section{A. Failure Mode}

The failure modes were depending on the test variables: size of the spliced reinforcement bars, spliced length and concrete cover depth Fig.4. It's observed that the failure mode for the two non-spliced beams (B1 \& B2) were almost similar, the flexure failure was happened at the maximum positive moment zone at load 87 and $88 \mathrm{kN}$ respectively. The flexural cracks at the mid span expanded gradually until they caused the flexural failure. For B3 and B4, the loading increasing up to the ultimate load, the flexural failure occurred for spliced beam NWRC (B3) outside the splicing zone at load level of $85 \mathrm{kN}$. Similarly for the spliced beam LWRC (B4), the flexure failure was occurred at the load level of $86 \mathrm{kN}$, also outside the splicing zone. The spliced NWC beam and LWC beam had almost the same failure load which reflects that the splicing was sufficient to transfer loads.

However, the failure mode for B5 $(\varnothing=16 \mathrm{~mm})$ was started as flexural, then it changed to be shear-tension due to expanding the flexural-shear cracks near the ends of the splice upward. The failure occurred at load level $172 \mathrm{kN}$ accompanied by a little bottom concrete cover loss. Also, the beam B6 $(\varnothing=22 \mathrm{~mm})$ exhibited a shear-compression failure mode near the support at load level $237 \mathrm{kN}$. The failure occurred outside the splicing zone and not far from the splice ends which was located far from the supports by $290 \mathrm{~mm}$ where the critical shear zone. Thus, it's observed that, increasing the bar size (reinforcing steel area) had enhanced the flexural capacity of the beam, while the shear capacity remained at the same level. Consequently, the shear failure was predicted.

The beam B7 with (stirrups spacing $=100 \mathrm{~mm}$ ) has the narrow cracks and flexural failure, while to the beam B8 with (stirrups spacing $=200 \mathrm{~mm}$ ) has wide cracks and shear failure. it's observed that increasing the transverse reinforcement enhances the shear capacity of the beam, but doesn't affect considerably its flexural capacity, as decreasing the stirrups spacing from (200mm) to (150mm) and from $(150 \mathrm{~mm})$ to $(100 \mathrm{~mm})$ was increased its flexural strength by (1. \%) up to (4.0\%) only. Regarding the beam B9 with (Ls = 350 ), was failed outside the splicing zone at $66 \mathrm{kN}$. Similarly, the beam the beam B10 with $(\mathrm{Ls}=45 \varnothing)$, the splitting failure was occurred outside the splicing zone at load level of $84 \mathrm{kN}$. In addition the failure mode was flexural failure for both beams. The beam B11 with (bottom concrete cover $10 \mathrm{~mm}$ ) was failed by the splitting failure at load level $92 \mathrm{kN}$ with crushing of its thin concrete cover. And beam B12 with (bottom concrete cover $40 \mathrm{~mm}$ ) was failed at load level $91 \mathrm{kN}$ without crushing of its concrete cover.
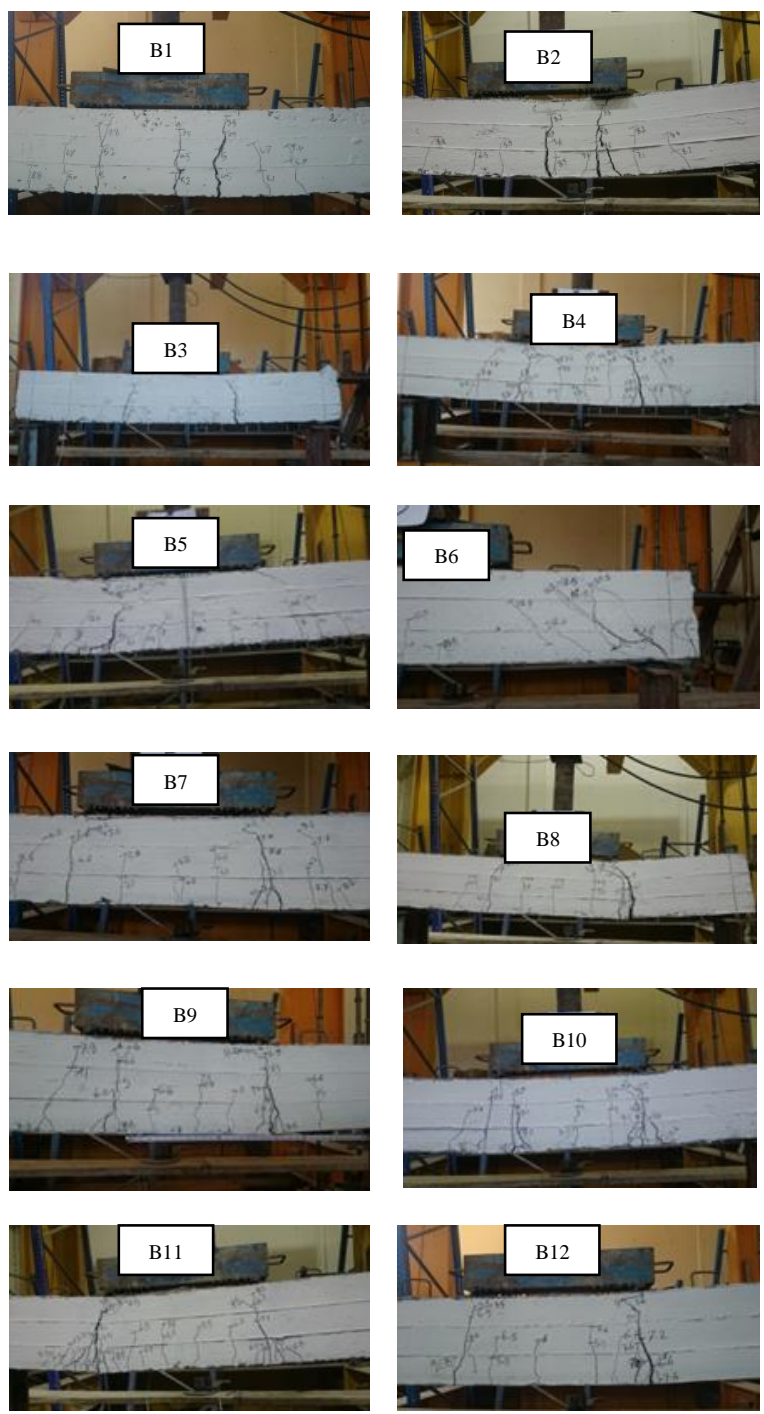

Fig. 4.Failure Mode of all tested beams.

\section{B. Load-Deflection Relationship}

The loads versus mid-span deflection relationships for all beams are shown in Fig 5. In order to study the relation between the applied load and the mid span deflection occurs at the different load stages for LWC beams (B4, B5 \& B6) with different longitudinal spliced bottom reinforcement bar sizes inside and comparing them with the reference non-spliced LWC beam (B2), Figure (5-a) was plotted from which it's clearly observed that the beam B6 $(\varnothing=22 \mathrm{~mm})$ sustained the greatest load levels due to its biggest bars' size which enhanced it flexural capacity, where $\varnothing$ is the diameter of the spliced bar, secondly came the beam B5 $(\varnothing=16 \mathrm{~mm})$, however they exhibited lower deflection values than the beam B4 $(\varnothing=10 \mathrm{~mm})$ which sustained the lowest load levels and greater deflection values due to its small bars' size. It's obvious that the beam (B4) has the greatest value of max deflection. Obviously, the resulted deflection of a beam at the sequent loading stages is inversely proportional to the reinforcement bar size within it, as increasing the spliced bar size within a beam from $(10 \mathrm{~mm})$ to $(22 \mathrm{~mm})$ decreased its ductility by (40\%).

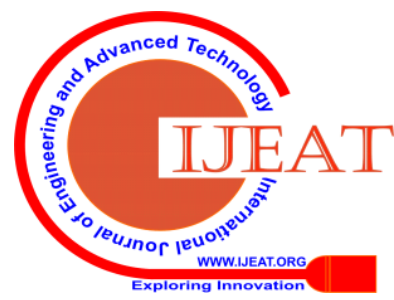




\section{Performance of Tension Lap-Splice in Lightweight Concrete}

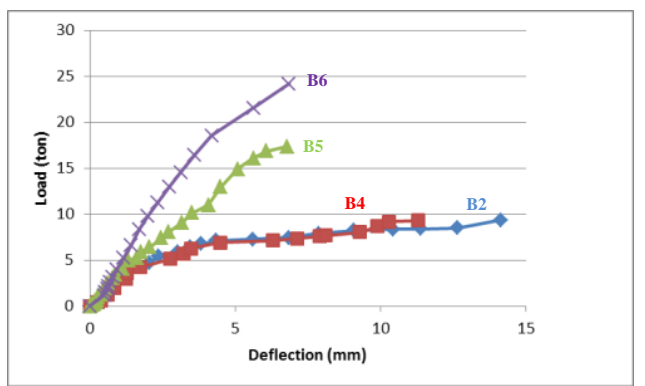

A - Bar Size

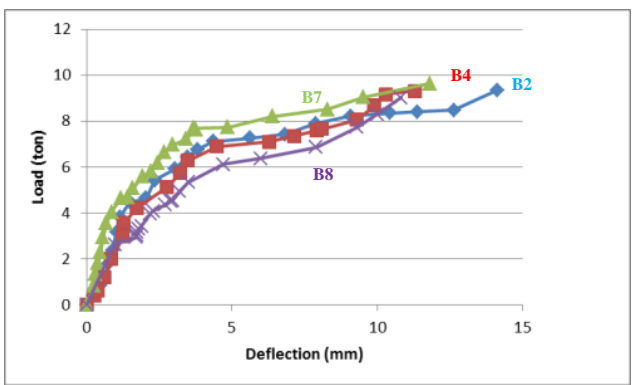

B-Stirrups Spacing

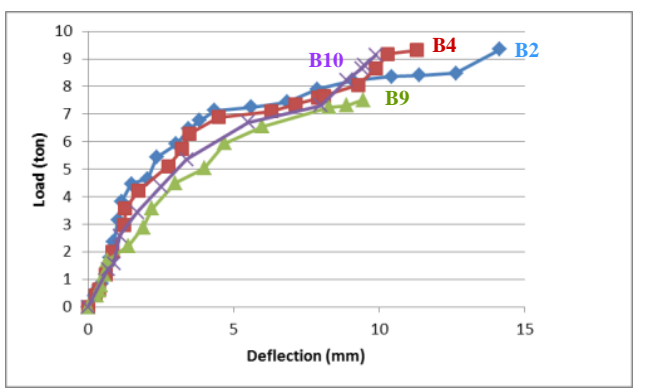

C-Splice Length

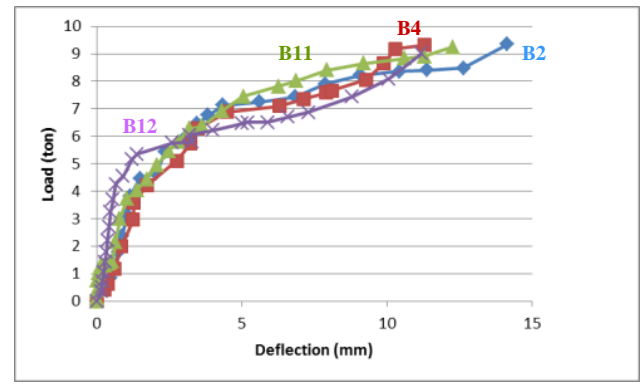

D-Cover Depth

Fig. 5. Load-Deflection.

In Figure (5-b) shows the load-mid span deflection relation for the spliced beams (B4, B7 \& B8) with different stirrups spacing and the non-spliced reference beam (B2), it's observed that the beam B7 (stirrups spacing 100mm) exhibited the lowest deflection values at different loading stages, secondly beam B4 (stirrups spacing $150 \mathrm{~mm}$ ) and the greatest deflection values were been recorded by the beam B7 (stirrups spacing 200mm). According to the max deflection value at the ultimate load, it's observed that increasing the transverse reinforcement, i.e. reducing the stirrups spacing, enhances the ductility of the beam, as reducing the stirrups spacing from $(200 \mathrm{~mm})$ to $(100 \mathrm{~mm})$ increased beam ductility by $(4 \%)$.

Figure (5-c) shows load-mid span deflection behaviour for LWRC spliced beams with variable splicing lengths (35Ø, $45 \varnothing$ and 55Ø) and the reference non-spliced beam (B2) where $\varnothing$ is the bar size of the spliced bar. It's observed that the beam B9 (with Ls $=35 \varnothing$ ) exhibited the greatest values of deflection at different load stages. At load level of $70 \mathrm{kN}$, the beam B9 $(\mathrm{Ls}=35 \varnothing)$ exhibited the greatest deflection value, secondly the beam B10 $(\mathrm{Ls}=45 \varnothing)$ and the lowest values were recorded by the beam B4 (Ls = 55Ø), however the max deflections recorded at the ultimate load stage which reflect the ductility decreased and consequently the ductility of the beam decreased by ( $25 \%$ ) and when decreasing the splicing length from (55Ø) to (35Ø).

Figure (5-d), it's observed that, at the linear stage of loading-deflection curve, the beam B12 (cover $=40 \mathrm{~mm}$ ) had exhibited almost the same deflection values. According to the max deflection recorded at ultimate load stage which reflects the ductility of the beam and since the ductility is mainly depends on the longitudinal as well as transversal reinforcement steel, it's observed that the ductility tends to be greater for the deeper stirrups, which is accompanied with the smaller concrete cover.

\section{Ductility and Strength}

Where the ductility (D) is defined as the ratio of the central deflection at the maximum load of the tested beam to that of the beam without tension lap splice and the strength measure $(\mathrm{K})$ is defined as the ultimate load of the tested specimen to that for the reference specimen without splice, table (IV) shows the summary of the results. The ductility (D) and strength $(\mathrm{K})$ calculated as the following equations:

(D) = max deflection for tested beam / max deflection for the reference beam.

$(\mathrm{K})$ = ultimate load for tested beam / ultimate load for the reference beam.

Table- III: Ductility and Strength

\begin{tabular}{|c|c|c|}
\hline Beam & (D) & (K) \\
\hline B2 & 1.00 & 1.0 \\
\hline B4 & 0.80 & 0.99 \\
\hline B5 & 0.48 & 1.85 \\
\hline B6 & 0.48 & 2.58 \\
\hline B7 & 0.84 & 1.02 \\
\hline B8 & 0.76 & 0.98 \\
\hline B9 & 0.67 & 0.87 \\
\hline B10 & 0.70 & 0.97 \\
\hline B11 & 0.87 & 0.98 \\
\hline B12 & 0.80 & 0.96 \\
\hline
\end{tabular}

According Table (III), it's observed that increasing the diameter of spliced bar improves stiffness and the strength, however decreases the ductility.

\section{Bond Failure Mechanism:}

For reinforcing bars in tension, two types of bond failure have been observed.The first type is the direct pull-out of the bar, which is expected to occur in case of using relatively small diameter bars with sufficiently large concrete cover distances and bar spacing, as if the bar is sufficient confined

by a mass of surrounding concrete; then, increasing the tensile force on the bar leading to overcoming the bonds of friction; hence, the concrete eventually crushes locally ahead of the bar deformations, and finally, the bar pull-out results.

The surrounding concrete remains intact, except the crushed concrete adjacent to the bar interface.The second observed type of failure is splitting of the concrete along the reinforcing bar.

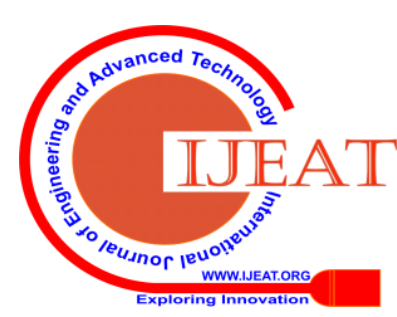


Such splitting comes mainly from wedging action of the bar when the ribs of the deformed bars bear against the concrete. As for the loaded bar for the first time, friction forces are present, however by increasing the load, i.e. increasing the tensile force affecting on the reinforcing bar, these bond transfer mechanisms are quickly lost, leaving the bond to be transferred by bearing in the deformations of the bar and then equal and opposite bearing stresses act on the concrete, these stresses affecting against the concrete having longitudinal and radial components, the later causes circumferential tensile stresses in the concrete around the bar. After a certain stage of loading, cover, confinement and bar spacing become insufficient to resist the lateral concrete tension resulting from the wedging effect of the bar deformations; hence the concrete will split parallel to the bar and the resulting crack will propagate out to the surface of the beam.

\section{E. Bond Strength}

According to the ACI - 318 [1], the bond stress was calculated by using Eq. (1) as shown in table (IV).

Figure 6 presents a comparison between the bond strength of each specimen. The bond strength in the splice region increases as the lap-spliced length increases [10]. Regarding ACI, it takes into account both the concrete and the reinforcing steel properties, thus it's fair to obtain precisely the resulted bond stresses which can be obtained as follows:

- The average splicing bond stress, $f_{b}=d_{b} *\left(f_{s}\right) / 4 l_{s}$

- The maximum bar stress:

$f_{\mathrm{s}}=E_{\mathrm{s}} *$ max steel strain

Where,

$\left(f_{\mathrm{s}}\right)$ Maximum bar stress.

- $\left(E_{S}\right)$ Modulus of elasticity.

- $\left(l_{s}\right)$ Spliced length.

- $\left(d_{b}\right)$ is the nominal diameter of the reinforcement.

TABLE- IV: Bond Stress

\begin{tabular}{|c|c|c|c|}
\hline Beam & $\begin{array}{c}\text { Max } \\
\text { Steel Strain } \\
\left(\boldsymbol{\mu}_{\text {str }}\right)\end{array}$ & $\begin{array}{c}\text { Measured } \\
\text { Steel Stress } \\
\left(\boldsymbol{f}_{\mathbf{s}}\right)(\mathbf{M p a})\end{array}$ & $\begin{array}{c}\text { Bond Stress by } \\
\text { ACI code } \\
\boldsymbol{f}_{\mathbf{b}} \text { (Mpa) }\end{array}$ \\
\hline B3 & 1475 & 295 & 1.34 \\
\hline B4 & 1548 & 310 & 1.41 \\
\hline B5 & 1435 & 287 & 1.30 \\
\hline B6 & 1295 & 259 & 1.18 \\
\hline B7 & 1725 & 345 & 1.12 \\
\hline B8 & 1233 & 247 & 1.99 \\
\hline B9 & 1396 & 279 & 1.57 \\
\hline B10 & 1411 & 282 & 1.26 \\
\hline B11 & 1388 & 325 & 1.48 \\
\hline B12 & 1626 & & 278 \\
\hline
\end{tabular}

1. The LWC is more ductile than the NWC.

2. The LWC and NWC spliced beam had almost the same failure load which reflects that the splicing was sufficient to transfer loads.

3. Although light-weight concrete has a good performance for tension lap splice, the splicing decreased the ductility of the LWC beams, as the continuity of the reinforcement bars within the non-spliced beam enables it to be more ductile while bearing loads.

4. The splice bar size is inversely proportional to the ductility, as increasing the splice bar size from $(10 \mathrm{~mm})$ to $(22 \mathrm{~mm})$ decreased its ductility by $(40 \%)$.

5. Increasing the transverse reinforcement, i.e. reducing the stirrups spacing, from $(200 \mathrm{~mm})$ to $(100 \mathrm{~mm})$ increased its ductility of the beam by (4\%).

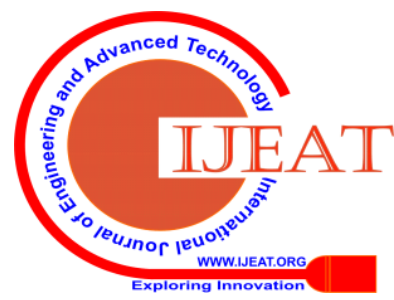


6. Decreasing the splicing length from (55Ø) to (35Ø), decreasing its ductility by $(25 \%)$ and also decreased the flexure strength by (12\%).

7. The concrete cover $(40 \mathrm{~mm})$ did not provide more additional bond strength; while the bottom concrete covers depth $(20 \mathrm{~mm})$ was efficient and preferable to providing the beam with the most accessible strength.

\section{REFERENCES}

1. ACI Building Code Requirements for Structural Concrete (ACI 318-14).

2. ACI Committee (213 R-87), Guide for Structural Lightweight Aggregate Concrete, ACI Manual of Concrete Practice, Part 1, American Concrete Institute, Farmington Hills, 1987.

3. ACI Committee 213R-0.3. Guide for structural lightweight aggregate concrete. American Concrete Institute, Farmington Hills, 2003.

4. DIN 50145 (1975) Testing of Metallic Materials; Tensile Test.

5. K. G. Babu, D. S. Babu, "Behavior of lightweight expanded polystyrene concrete containing silica fume", Cement and Concrete Research Vol. 33, pp.755-762, 2003.

6. A. Kan, R. Demirbog, "A novel material for lightweight concrete production", Cement \& Concrete Composites Vol. 31, pp. 489-495, 2009.

7. Kan A, Demirbog a R. Effect of cement and EPS beads ratios on compressive strength and density of lightweight concrete. Indian J Eng Mater Sci Vol.14, pp158-62, 2007.

8. W.C. Tang, Y. Lo, A. Nadeem, "Mechanical and drying shrinkage properties of structural-graded polystyrene aggregate concrete", Cement \& Concrete Composites, Vol.30, pp. 403-409, 2008.

9. E. Sancak, O. Simsek, A. C. Apay, "A comparative study on the bond performance between rebar and structural lightweight pumice concrete with/without admixture", International Journal of the Physical Sciences Vol. 6(14), pp. 3437-3454, 18 July,.

10. Ibrahim, W "Behavior of Lap-Splice Reinforcement Bars in Lightweight Concrete,"ICCE-27 - The twenty-seventy annual international conference on composites/Nano Engineering. Granada, Spain 14-20 July 2019.

11. B. Chen, J. Liu, "Properties of lightweight expanded polystyrene concrete reinforced with steel fiber", Cement and Concrete Research, Vol. 34, pp. 1259-1263, 2004.

12. S. H. Perry, P. H. Bischoff, K. Yamura, "Mix details and material behavior of polystyrene aggregate concrete", Magazine of Concrete Research, Vol. 43, pp. 71-76, 1991.

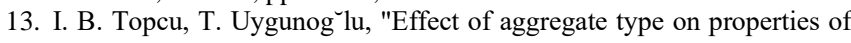
hardened self-consolidating lightweight concrete (SCLC)", Construction and Building Materials Vol. 24, pp. 1286-1295, 2010.

14. J.M. Chi, R. Huang, C.C. Yang, J.J. Chang, "Effect of aggregate properties on the strength and stiffness of lightweight concrete", Cement \& Concrete Composites Vol. 25, pp. 197-205, 2003.

15. T. Y. Lo, W.C. Tang, H.Z. Cui," The effects of aggregate properties on lightweight concrete", Building and Environment 3025-3029 Vol. 42, pp. 3025-3029, 2007.

16. K. G. Babu, D. S. Babu, "Performance of fly ash concretes containing lightweight EPS aggregates", Cement \& Concrete Composites , Vol 26, pp. 605-611, 2004

17. B. S. Hamad, M. H. Harajli, and G. Jumaa, "Effect of fiber reinforcement on bond strength of tension lap splices in high strength concrete," ACI Structural Journal, vol. 98, no. 5, pp. 638-647, 2001.

\section{AUTHORS PROFILE}

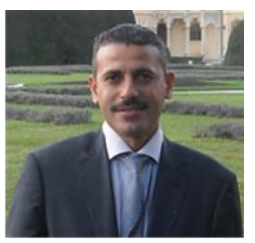

Dr. Wael Ibrahim. Instructor of Concrete Structures and Steel Structures at the faculty of engineering, Helwan University. Well experienced in both steel and concrete structural design and construction supervision.EDUCATIONPhD in Civil and Environmental Engineering University of Aachen, RWTH, GermanySeptember- 2011 M.Sc. of Structural Engineering

Faculty of Engineering - Mataria, Helwan University, Cairo, Egypt

July 2002B.S. in Civil Engineering, grade very good with honor degree Faculty of Engineering - Mataria, Helwan University, Cairo, Egypt

May 1996

Rana Ahmed, Design engineer of Concrete Structures. EDUCATION B.SC. in Civil Engineering (2013), El Shorouk Academy, Cairo, Egypt. M.Sc. of Structural Engineering Faculty of Engineering

Mataria, Helwan University, Cairo, Egypt July 2002. 